\title{
Medicinal Plants Used as Antitumor Agents in Brazil: An Ethnobotanical Approach
}

\author{
Joabe Gomes de Melo, ${ }^{1,2}$ Ariane Gaspar Santos, ${ }^{2}$ Elba Lúcia Cavalcanti de Amorim, ${ }^{2}$ \\ Silene Carneiro do Nascimento, ${ }^{3}$ and Ulysses Paulino de Albuquerque ${ }^{1}$ \\ ${ }^{1}$ Departamento de Biologia, Universidade Federal Rural de Pernambuco, Rua Dom Manoel de Medeiros, $s / n$, \\ 52171-900 Recife, PE, Brazil \\ ${ }^{2}$ Departamento de Ciências Farmacêuticas, Centro de Ciências da Saúde, Universidade Federal de Pernambuco, \\ Avenida Prof. Arthur de Sá, s/n, 50740-521 Recife, PE, Brazil \\ ${ }^{3}$ Departamento de Antibióticos, Universidade Federal de Pernambuco, Avenida Prof. Arthur de Sá, s/n, 50740-521 Recife, PE, Brazil
}

Correspondence should be addressed to Joabe Gomes de Melo, jgm2005@ig.com.br and

Ulysses Paulino de Albuquerque, upa@db.ufrpe.br

Received 3 July 2010; Revised 15 November 2010; Accepted 9 January 2011

Copyright (C) 2011 Joabe Gomes de Melo et al. This is an open access article distributed under the Creative Commons Attribution License, which permits unrestricted use, distribution, and reproduction in any medium, provided the original work is properly cited.

In this study, we describe the medicinal plants that have been reported to be antitumor agents and that have been used in ethnobotanic research in Brazil to answer the following questions: what is the abundance of plants reported to be antitumor in Brazil? Have the plant species used for tumor treatment in traditional Brazilian medicine been sufficiently examined scientifically? Our analysis included papers published between 1980 and 2008. A total of 84 medicinal plant species were reported to be used for cancer and tumor prevention or treatment; $69.05 \%$ of these were cited as being used for the treatment of tumors and cancer in general and $30.95 \%$ for specific tumors or cancers. The plants that were cited at a higher frequency were Aloe vera, Euphorbia tirucalli, and Tabebuia impetiginosa. At least, one pharmacological study was found for $35.71 \%$ of the species. Majority of the studies selected were conducted in rural communities and urban areas and in areas with traditional healers in Brazil. We found the following molecules to be the most studied in vitro and in vivo: silibinin, $\beta$-lapachone, plumbagin and capsaicin. The species addressed here constitute interesting objects for future studies to various professionals in the field of natural products.

\section{Introduction}

In Brazil, it is estimated that there will be more than 489,270 new cases of cancer in 2011 [1]. Also known as neoplastic tumors, malignant tumors are characterized by uncontrolled growth of transformed cells [2], which can rupture the basal membrane, attack and invade the surrounding tissues, and may metastasize [3].

There are some limitations in the treatment of cancer with chemotherapy, that in general provoke various toxic reactions [4]. In addition, solid tumors are generally resistant to chemotherapy due to the inability of the drugs to access hypoxic cells [5]. Moreover, many antineoplastic agents are not specific to cancer cells and can also damage healthy cells, especially those with rapid turnover, such as gastrointestinal and immune cells [2]. Because of this, many patients with cancer around the world have resorted to complementary and alternative therapies as adjuvant treatment in relation to official (radiation, chemotherapy, and surgery), as the use of plants [6].

Plant diversity is an important source of new molecules. More than $60 \%$ of the anticancer agents used today are derived directly or indirectly from natural sources [7]. Higher plants have been one of the largest sources of new compounds with pharmacological activity. For example, the species Catharanthus roseus (L.) G. Don (Apocynaceae) produces several alkaloids, two of which, vincristine and vinblastine, have anticancer activity [4]. Taxus brevifolia Nutt., pacific yew, produces a diterpenic alkaloid known as taxol, which has been shown to act against advanced ovarian cancer [8]. $\beta$-lapachone and lapachol are extracted from the bark of Tabebuia impetiginosa (Mart. ex DC.) 
Standl, which is native to Brazil; lapachol is sold in Brazil by Pernambuco Pharmaceutical Laboratory (LAFEPE) and is used for treatment of various neoplasias.

Ethnobotanical approach is a strategy that has successfully identified new bioactive molecules from diverse plants. In this approach, the information obtained from traditional communities about the use of medicinal plants is combined with chemical/pharmacological studies performed in laboratories [9]. This strategy has been helpful in plant pharmacological research and has yielded better results than the random approach used in different experimental models $[10,11]$.

Brazil is the country with the highest plant diversity on the planet, with approximately 55,000 species of higher plants [12] distributed in several ecosystems: Atlantic forest, Amazon Forest, Cerrado, Caatinga, Pantanal, and Pampas. In addition, the country also has an enormous cultural diversity that is reflected in the different ways its natural resources are used [13]. In general, the use of medicinal plants in Brazil is strongly influenced by the cultural miscegenation, the introduction of exotic species by Africans and Europeans since the times of the colonization and the native indigenous people who make use of the local plant diversity. Such immense plant and cultural diversity has favored the diversification of a popular pharmacopoeia based on medicinal plants [14].

This study presents a review of the medicinal plants reported in ethnobotanical studies conducted in Brazil that have antitumor properties. Our results aimed to answer the following two questions: (1) what is the abundance of plants reported to be antitumor properties in Brazil? and (2) have the plant species used for tumor treatment in traditional Brazilian medicine been sufficiently examined scientifically?

\section{Materials and Methods}

2.1. Survey and Study Selection. Our survey of ethnobotanical studies was performed using five databases (SCIELO, SCIRUS, SCOPUS, BIOLOGICAL ABSTRACTS, and WEB OF SCIENCE) using the following four combinations of keywords: ethnobotany AND Brazil AND medicinal plants, ethnobotany AND Brazilian medicinal plants, ethnopharmacology AND Brazil AND medicinal plants, and ethnopharmacology AND Brazilian medicinal plants. Our analysis included papers published between 1980 and 2008. From the studies obtained from our search, we selected only those of an ethnobotanical nature performed in Brazil and that cited at least one plant with popular antitumor properties. All information regarding the plant and its use, such as popular name, species, plant part, therapeutic indication, community type, biome, and location, where the study was carried out, was taken directly from the selected reports. For our analysis, we considered all of the plants as those that were popularly recommended for the treatment of tumors and/or cancer in general or for the treatment of more specific cancers, such as leukemia, warts, or cancers of specific organs or human body parts.

Some studies did not specify the culture of the population studied (e.g., indigenous, farmers, quilombola, or urban), and in those cases, we designated it as a "local population." The Brazilian ecosystems were classified as Amazon, Cerrado (Brazilian savanna), Atlantic forest, Caatinga (tropical dry lands), Pantanal (tropical wetland), and Pampas (South America plain), as defined by the Brazilian Institute of Geography and Statistics (IBGE). In those studies, where the biome type was not provided, the correct biome was obtained from the IBGE, to supplement the data.

The frequency or the number of times a given plant species was cited in the different studies analyzed was recorded. Pharmacological studies on the classified plants was verified in the aforementioned databases using the following keyword combinations: species name AND tumor and species name AND cancer. For the species names, all of the scientific synonyms listed in the database of the Missouri Botanical Garden (http//www.tropicos.org/) were used. For the evaluation of the pharmacological studies available for each plant species, we considered both in vitro and in vivo studies related to cancer or tumors in humans and animals.

\section{Results}

3.1. Survey of Ethnobotanical Studies. Out of 293 studies found using the different keyword combinations, 39 were selected according to the inclusion criteria. Of these selected studies, $89.7 \%$ were published between 2000 and 2008. We did not find any studies published during the 1980s. Six bibliographic review papers contained the highest number of plant species cited as antitumor $(\bar{X}=8.67)$. Reports considered reviews were those that used data from the published primary literature. The average number of plant species cited, without taking reviews into account, was 2.15. If we took into account all studies including reviews, the average number of species cited was 3.74. The similarity between the plant species cited in the reviews and the primary literature was $29.76 \%$.

Majority of the studies were performed in rural communities (farm areas) and urban areas and in areas with traditional healers $(>82 \%)$. A minority of the studies were performed with indigenous and Quilombola populations. We found that a higher number of plants were cited as being antitumor in the Caatinga (27.38\%; 23 spp.), Cerrado $(25.0 \% ; 21 \mathrm{spp}$.$) and Atlantic forest (22.6\%; 19 \mathrm{spp}$.$) ,$ ecosystems. Communities in the Amazon Forest and the Pampas were each represented in $5.61 \%$ of the studies, which corresponds to six species. The studies that did not specify the type of vegetation or the location where the study was carried out but that were influenced by two different types of ecosystems corresponded to $20.51 \%$ of the studies, representing a total of 41 plant species cited. There was a $14.29 \%$ similarity between the species found in two or more ecosystems.

3.2. Survey of Ethnobotanical Studies. A total of 84 medicinal plant species were reported in the ethnobotanical/ethnopharmacological literature as being used for the treatment or prevention of cancer and tumors, and these species were distributed among 42 families and 63 genera 
TABLE 1: Species of medicinal plants cited as being antitumor by traditional and nontraditional communities in Brazil with their plant parts used, indication, occurrence, and pharmacological studies.

\begin{tabular}{|c|c|c|c|c|}
\hline Family/species & Plant parts used & Indication & $\begin{array}{l}\text { Pharmacological } \\
\text { study/molecules evaluated }\end{array}$ & $\begin{array}{l}\text { Occurrence } \\
\text { (reference) }\end{array}$ \\
\hline \multicolumn{5}{|l|}{ Amaranthaceae } \\
\hline Iresine herbstii Hook & Leaf & Cancer & - & $2[15,16]$ \\
\hline \multicolumn{5}{|l|}{ Anacardiaceae } \\
\hline Anacardium occidentale L. & Resin & Wart & $\begin{array}{l}\text { In vitro, in vivo and } \\
\text { clinical/Anacardic acid, } \\
\text { polysaccharides, } \\
\text { oligosaccharides, } \beta \text {-galactose, } \\
\text { and proteins }[17-20]\end{array}$ & $2[21,22]$ \\
\hline Myracrodruon urundeuva Allemão & Bark & $\begin{array}{l}\text { Tumors, } \\
\text { neoplasias }\end{array}$ & - & $2[23,24]$ \\
\hline \multicolumn{5}{|l|}{ Annonaceae } \\
\hline Rollinia leptopetala R.E. Fr. & Bark & Tumors & - & $2[22,25]$ \\
\hline Rolliniopsis leptopetala (R.E. Fr.) Saff. & Bark & Tumors & - & $1[13]$ \\
\hline \multicolumn{5}{|l|}{ Apocynaceae } \\
\hline Forsteronia refracta Müll. Arg. & Latex & Cancer & $\begin{array}{l}\text { In vitro/SL0101 (a kaempferol } \\
\text { glycoside) [26] }\end{array}$ & $1[27]$ \\
\hline Hancornia speciosa Gomes & Latex & Cancer & In vitro $[28]$ & $1[29]$ \\
\hline Himatanthus articulatus (Vahl) Woodson & Latex & $\begin{array}{l}\text { Tumors, } \\
\text { cancer }\end{array}$ & - & $1[22]$ \\
\hline Himatanthus bracteatus (A. DC.) Woodson & Latex & $\begin{array}{l}\text { Tumors, } \\
\text { cancer }\end{array}$ & - & $1[22]$ \\
\hline Himatanthus obovatus (Müll. Arg.) Woodson & Latex & Cancer & In vitro $[30]$ & $1[31]$ \\
\hline Macrosiphonia velame (A. St.-Hil.) Müll. Arg. & $\begin{array}{l}\text { Whole plant, } \\
\text { root }\end{array}$ & Tumors & - & $1[31]$ \\
\hline \multicolumn{5}{|l|}{ Arecaceae } \\
\hline Orbignya phalerata Mart. & Fruit & Leukemia & In vitro [32] & $1[22]$ \\
\hline \multicolumn{5}{|l|}{ Asclepiadaceae } \\
\hline Marsdenia altissima (Jacq.) Dugand & Bark & Cancer & - & $1[22]$ \\
\hline \multicolumn{5}{|l|}{ Asteraceae } \\
\hline Acanthospermum hispidum DC. & $\begin{array}{l}\text { Leaf, flower, } \\
\text { root }\end{array}$ & Cancer & In vitro and in vivo $[33,34]$ & $2[35,36]$ \\
\hline Aster squamatus (Spreng.) Hieron. & Aerial parts & Cancer & - & $2[15,37]$ \\
\hline Calendula officinalis L. & Whole plant & Cancer & $\begin{array}{l}\text { In vitro and in vivo/calenduloside } \\
\mathrm{F} 6^{\prime}-O-n \text {-butyl-ester and } \\
\text { calenduloside } \mathrm{G} 6^{\prime} \text {-O-methyl } \\
\text { ester }[38]\end{array}$ & $1[15]$ \\
\hline Silybum marianum (L.) Gaertn. & - & $\begin{array}{l}\text { Internal } \\
\text { tumors }\end{array}$ & $\begin{array}{l}\text { In vitro and in vivo/silybinin and } \\
\text { silimarin }[39,40]\end{array}$ & $1[16]$ \\
\hline \multicolumn{5}{|l|}{ Bignoniaceae } \\
\hline Tabebuia impetiginosa (Mart. ex DC.) Standl. & $\begin{array}{l}\text { Bark, flower, } \\
\text { bast }\end{array}$ & $\begin{array}{l}\text { Cancer and } \\
\text { tumors }\end{array}$ & $\begin{array}{l}\text { In vitro and in vivo/ } \beta \text {-lapachone } \\
{[41,42]}\end{array}$ & $6[13,22,43-46]$ \\
\hline Tecoma violacea & Bark & Cancer & - & $1[47]$ \\
\hline \multicolumn{5}{|l|}{ Boraginaceae } \\
\hline Symphytum officinale L. & Leaf & $\begin{array}{l}\text { Leukemia, } \\
\text { cancer, mouth } \\
\text { cancer, skin } \\
\text { cancer }\end{array}$ & In vitro [48] & $\begin{array}{c}5 \\
{[23,45,46,49,50]}\end{array}$ \\
\hline
\end{tabular}


TABle 1: Continued.

\begin{tabular}{|c|c|c|c|c|}
\hline Family/species & Plant parts used & Indication & $\begin{array}{l}\text { Pharmacological } \\
\text { study/molecules evaluated }\end{array}$ & $\begin{array}{l}\text { Occurrence } \\
\text { (reference) }\end{array}$ \\
\hline \multicolumn{5}{|l|}{ Caricaceae } \\
\hline Carica papaya L. & $\begin{array}{l}\text { Flower, fruit, } \\
\text { latex }\end{array}$ & Wart & $\begin{array}{l}\text { In vitro/5,7-dimethoxycoumarin, } \\
\text { Lycopene and Benzyl } \\
\text { isothiocyanate }[51-53]\end{array}$ & $2[13,54]$ \\
\hline \multicolumn{5}{|l|}{ Caryocaraceae } \\
\hline Caryocar coriaceum Wittm. & - & Tumors & - & $1[55]$ \\
\hline \multicolumn{5}{|l|}{ Cecropiaceae } \\
\hline Cecropia hololeuca Miq. & - & $\begin{array}{l}\text { Cancerous } \\
\text { wounds }\end{array}$ & - & $1[56]$ \\
\hline Cecropia peltata L. & - & $\begin{array}{l}\text { Cancerous } \\
\text { wounds }\end{array}$ & - & $1[56]$ \\
\hline \multicolumn{5}{|l|}{ Celastraceae } \\
\hline Maytenus ilicifolia (Schrad.) Planch. & Leaf, root & $\begin{array}{l}\text { Cancer, skin } \\
\text { cancer, tumors }\end{array}$ & $\begin{array}{l}\text { In vitro/Pristimerin, } \\
6 \text {-oxotingenol and Erythrodiol } \\
{[57-59]}\end{array}$ & $4[16,37,60,61]$ \\
\hline Maytenus obtusifolia Mart. & Leaf & Cancer & - & $1[22]$ \\
\hline Maytenus rigida Mart. & Bark & Cancer & - & $1[22]$ \\
\hline \multicolumn{5}{|l|}{ Chenopodiaceae } \\
\hline Chenopodium ambrosioides L. & $\begin{array}{l}\text { Stem, leaf, } \\
\text { whole plant }\end{array}$ & Cancer & $\begin{array}{l}\text { In vitro and in vivo/ascaridol } \\
{[62,63]}\end{array}$ & $2[13,31]$ \\
\hline \multicolumn{5}{|l|}{ Cochlospermaceae } \\
\hline Cochlospermum regium (Schrank) Pilg. & Root & Cancer & - & $1[31]$ \\
\hline \multicolumn{5}{|l|}{ Crassulaceae } \\
\hline Cotyledon orbiculata L. & - & Cancer & - & $1[64]$ \\
\hline \multicolumn{5}{|l|}{ Euphorbiaceae } \\
\hline Cnidoscolus obtusifolius Pohl ex Baill. & Leaf, flower & $\begin{array}{l}\text { Cancer and } \\
\text { tumors }\end{array}$ & - & $3[13,35,36]$ \\
\hline $\begin{array}{l}\text { Cnidoscolus phyllacanthus (Müll. Arg.) Pax \& L. } \\
\text { Hoffm. }\end{array}$ & $\begin{array}{l}\text { Stem, bark, bast, } \\
\text { látex, root }\end{array}$ & Wart & - & $2[13,21]$ \\
\hline Cnidoscolus urens (L.) Arthur & Root & Cancer & - & $1[23]$ \\
\hline Croton antisyphiliticus Mart. & Leaf & Tumors & - & $1[65]$ \\
\hline Croton urucurana Baill. & - & Cancer & - & $1[55]$ \\
\hline Euphorbia phosphorea Mart. & Stem, latex & Wart & - & $3[13,22,47]$ \\
\hline Euphorbia prostrata Aiton & Latex & Wart & - & $3[13,22,47]$ \\
\hline Euphorbia tirucalli L. & $\begin{array}{l}\text { Latex, aerial } \\
\text { parts, leaf }\end{array}$ & $\begin{array}{l}\text { Cancer and } \\
\text { wart }\end{array}$ & - & $\begin{array}{c}6[15,16,22,64 \\
66,67]\end{array}$ \\
\hline Manihot esculenta Crantz & Leaf, látex, root & Wart & $\begin{array}{l}\text { In vitro/linamarin, esculentoic } \\
\text { acids } \mathrm{A} \text { and } \mathrm{B}[68,69]\end{array}$ & $2[13,47]$ \\
\hline \multicolumn{5}{|l|}{ Fabaceae } \\
\hline Anadenanthera colubrina (Vell.) Brenan & $\begin{array}{l}\text { Stem, bark, bast, } \\
\text { flower, leaf, fruit }\end{array}$ & Cancer & $\begin{array}{l}\text { In vivo/acidic } \\
\text { heteropolysaccharide [70] }\end{array}$ & $1[13]$ \\
\hline Bauhinia forficata Link & Leaf & Cancer & In vitro/HY52 [71] & $1[60]$ \\
\hline Copaifera langsdorffii Desf. & - & Tumors & In vitro/kaurenoic acid [72] & $1[55]$ \\
\hline Copaifera multijuga Hayne & Oil of fruit & Cancer & In vitro and in vivo [73] & $1[22]$ \\
\hline Copaifera reticulata Ducke & Whole plant & Cancer & - & $1[22]$ \\
\hline Parapiptadenia rigida (Benth.) Brenan & - & Tumors & - & $1[50]$ \\
\hline Senna occidentalis (L.) Link & Leaf, seed, root & Cancer & In vitro $[74]$ & $2[13,36]$ \\
\hline \multicolumn{5}{|l|}{ Iridaceae } \\
\hline Eleutherine bulbosa (Mill.) Urb. & Leaf, bulb & Cancer & - & $1[67]$ \\
\hline
\end{tabular}


Table 1: Continued.

\begin{tabular}{|c|c|c|c|c|}
\hline Family/species & Plant parts used & Indication & $\begin{array}{l}\text { Pharmacological } \\
\text { study/molecules evaluated }\end{array}$ & $\begin{array}{l}\text { Occurrence } \\
\text { (reference) }\end{array}$ \\
\hline \multicolumn{5}{|l|}{ Lamiaceae } \\
\hline Leucas martinicensis (Jacq.) R. Br. & Leaf & Benign tumors & - & $1[75]$ \\
\hline \multicolumn{5}{|l|}{ Lecythidaceae } \\
\hline Cariniana rubra Gardner ex Miers & Bark & $\begin{array}{l}\text { Tumors } \\
\text { (myoma) }\end{array}$ & - & $1[61]$ \\
\hline \multicolumn{5}{|l|}{ Liliaceae } \\
\hline Aloe arborescens Mill. & Leaf & $\begin{array}{l}\text { Cancer, } \\
\text { prostate cancer }\end{array}$ & $\begin{array}{l}\text { In vitro, in vivo and clinical/Aloin } \\
\text { [76-78] }\end{array}$ & $\begin{array}{c}6[15,16,64,66 \\
79,80]\end{array}$ \\
\hline Aloe soccotrina DC. & Leaf & Leukemia & - & $2[22,81]$ \\
\hline Aloe vera (L.) Burm. f. & $\begin{array}{l}\text { Leaf, root, stem } \\
\text { and sap }\end{array}$ & Cancer & $\begin{array}{l}\text { In vitro and in vivo/aloe-emodin } \\
\text { and aloctin I }[82,83]\end{array}$ & $\begin{array}{c}8[13,16,23,31 \\
55,60,84,85]\end{array}$ \\
\hline \multicolumn{5}{|l|}{ Lythraceae } \\
\hline Lafoensia pacari A. St.-Hil. & Bark & Cancer & - & $1[61]$ \\
\hline \multicolumn{5}{|l|}{ Malvaceae } \\
\hline Abutilon grandifolium (Willd.) Sweet & Leaf & $\begin{array}{l}\text { Cancer and } \\
\text { myoma }\end{array}$ & - & $2[16,79]$ \\
\hline \multicolumn{5}{|l|}{ Myrcinaceae } \\
\hline Rapanea guianensis Aubl. & $\begin{array}{l}\text { Branches with } \\
\text { leaf }\end{array}$ & Tumors & In vitro/rapanone $[86]$ & $1[87]$ \\
\hline Rapanea umbellata (Mart.) Mez & $\begin{array}{l}\text { Branches with } \\
\text { leaf }\end{array}$ & Tumors & - & $1[87]$ \\
\hline \multicolumn{5}{|l|}{ Myrtaceae } \\
\hline Myrciaria herbacea O. Berg & Root & Cancer & - & $1[31]$ \\
\hline \multicolumn{5}{|l|}{ Nyctaginaceae } \\
\hline Boerhavia diffusa L. & Leaf, root & Leukemia & $\begin{array}{l}\text { In vivo/punarnavine, } \\
\text { boeravinones } \mathrm{G} \text { and } \mathrm{H}[88,89]\end{array}$ & $1[31]$ \\
\hline Guapira pernambucensis (Casar.) Lundell & Bark & Wart & - & $1[22]$ \\
\hline \multicolumn{5}{|l|}{ Papaveraceae } \\
\hline Chelidonium majus L. & Latex & Wart & $\begin{array}{l}\text { In vitro and in vivo/chelidonine, } \\
\text { sanguinarine, chelerythrine, and } \\
\text { nucleases (CMN1 and CMN2) } \\
{[90-92]}\end{array}$ & $1[15]$ \\
\hline \multicolumn{5}{|l|}{ Piperaceae } \\
\hline Ottonia leptostachya Kunth & Whole plant & Wart & - & $1[22]$ \\
\hline Piper regnellii (Miq.) C. DC. & Leaf, aerial parts & Myoma & - & $1[37]$ \\
\hline \multicolumn{5}{|l|}{ Plantaginaceae } \\
\hline Plantago australis Lam & $\begin{array}{l}\text { Leaf, root, } \\
\text { whole plant, and } \\
\text { inflorescence }\end{array}$ & $\begin{array}{l}\text { Tumors, } \\
\text { cancer and } \\
\text { prevent cancer }\end{array}$ & - & $3[37,50,79]$ \\
\hline Plantago major L. & $\begin{array}{l}\text { Leaf, root, } \\
\text { whole plant and } \\
\text { inflorescence }\end{array}$ & Prevent cancer & In vitro and in vivo $[93,94]$ & $1[79]$ \\
\hline Plantago tomentosa Lam. & - & Cancer & - & $2[16,37]$ \\
\hline \multicolumn{5}{|l|}{ Plumbaginaceae } \\
\hline Plumbago scandens L. & $\begin{array}{l}\text { Bark, leaf, root, } \\
\text { whole plant }\end{array}$ & Wart & $\begin{array}{l}\text { In vivo and in vitro/plumbagin } \\
{[95,96]}\end{array}$ & $4[13,21,22,25]$ \\
\hline \multicolumn{5}{|l|}{ Pteridaceae } \\
\hline Adiantum raddianum C. Presl & Aerial parts & Cancer & - & $2[37,64]$ \\
\hline \multicolumn{5}{|l|}{ Rubiaceae } \\
\hline Psychotria ipecacuanha (Brot.) Stokes & Whole plant & Cancer & $\begin{array}{l}\text { In vitro and in vivo/emetine } \\
{[97,98]}\end{array}$ & $1[23]$ \\
\hline
\end{tabular}


TABle 1: Continued.

\begin{tabular}{|c|c|c|c|c|}
\hline Family/species & Plant parts used & Indication & $\begin{array}{l}\text { Pharmacological } \\
\text { study/molecules evaluated }\end{array}$ & $\begin{array}{l}\text { Occurrence } \\
\text { (reference) }\end{array}$ \\
\hline \multicolumn{5}{|l|}{ Sapindaceae } \\
\hline Cardiospermum oliveirae Ferrucci & $\begin{array}{l}\text { Stem, leaf, } \\
\text { flower, aerial } \\
\text { parts }\end{array}$ & Tumors & - & $3[13,22,36]$ \\
\hline Serjania erecta Radlk. & Leaf, root & Cancer & - & $1[61]$ \\
\hline \multicolumn{5}{|l|}{ Simaroubaceae } \\
\hline Simaba suffruticosa Engl. & Root & Cancer & - & $1[31]$ \\
\hline \multicolumn{5}{|l|}{ Solanaceae } \\
\hline Capsicum frutescens $\mathrm{L}$. & Leaf & Tumor & $\begin{array}{l}\text { In vitro and in vivo/capsaicin } \\
{[99,100]}\end{array}$ & $1[60]$ \\
\hline Solanum americanum Mill. & Leaf & Myoma & $\begin{array}{l}\text { In vitro and in vivo/glycoprotein } \\
\text { and solanine }[101,102]\end{array}$ & $1[60]$ \\
\hline Solanum paniculatum $\mathrm{L}$. & Root, leaf, fruit & $\begin{array}{l}\text { Internal } \\
\text { tumors }\end{array}$ & - & $1[87]$ \\
\hline \multicolumn{5}{|l|}{ Tiliaceae } \\
\hline Luehea paniculata Mart. & Bark, leaf & Tumors & - & $1[103]$ \\
\hline \multicolumn{5}{|l|}{ Turneraceae } \\
\hline Turnera ulmifolia L. & $\begin{array}{l}\text { Leaf, root, } \\
\text { whole plant }\end{array}$ & Cancer & - & $1[13]$ \\
\hline \multicolumn{5}{|l|}{ Verbenaceae } \\
\hline Stachytarpheta cayennensis (Rich.) Vahl & Leaf & Cancer & - & $2[37,64]$ \\
\hline Vitex triflora Vahl & Leaf, latex & Wart & - & $2[22,104]$ \\
\hline \multicolumn{5}{|l|}{ Violaceae } \\
\hline Viola odorata L. & - & Cancer & $\begin{array}{l}\text { In vitro and in vivo/cycloviolacin } \\
\text { O2 [105] }\end{array}$ & $1[64]$ \\
\hline \multicolumn{5}{|l|}{ Vitaceae } \\
\hline Cissus coccinea (Baker) Mart. ex Planch. & Leaf, root & Wart & - & $1[22]$ \\
\hline Cissus decidua Lombardi & $\begin{array}{l}\text { Stem, leaf, } \\
\text { flower, aerial } \\
\text { parts }\end{array}$ & Cancer & - & $3[13,22,36]$ \\
\hline Cissus duarteana Cambess. & Sap and root & Wart & - & $1[103]$ \\
\hline Cissus erosa Rich. & Aerial parts & Wart & - & $2[21,22]$ \\
\hline \multicolumn{5}{|l|}{ Zingiberaceae } \\
\hline Costus spiralis (Jacq.) Roscoe & - & Prostate cancer & - & $1[84]$ \\
\hline
\end{tabular}

(Table 1). The more highly represented botanic families were: Euphorbiaceae (9 spp.), Fabaceae (7 spp.), Apocynaceae (6 spp.), Asteraceae, and Vitaceae (4 spp. each). The genera with the highest number of species were: Cissus (4 spp.), Himatanthus, Maytenus, Cnidoscolus, Euphorbia, Copaifera, Aloe, and Plantago (3 spp. each). The plants most frequently cited were Aloe vera (eight), Aloe arborescens, Euphorbia tirucalli and Tabebuia impetiginosa (each cited six times), and Symphytum officinale (five). Of these, only Tabebuia impetiginosa is native to Brazil.

Majority of the plant species were reported to be used for the treatment of tumors and cancer in general (69.05\%), and a smaller proportion $(30.95 \%)$ were reported to be used for the treatment of specific tumors, such as warts, leukemia, myoma, or cancers of the mouth, skin, and prostate. $S$. officinale stands out from the other plants because it was reported to be used for the treatment of cancer in general, leukemia and mouth and skin cancers. In vitro and in vivo studies related directly to tumors of animal origin were not found for 55 (64.29\%) of the species analyzed here.

3.3. Survey of Ethnobotanical Studies. We found at least one type of pharmacological study for $35.71 \%$ of the plant species (30 taxa). Considering only the plant species for which we found pharmacological studies, we found only $14.29 \%$ (4 taxa) of the species or their molecules were used for clinical studies, and $39.39 \%$ of the plants (12 taxa) were used to perform in vitro studies of their extracts or associated molecules (Figure 1). From the plants for which we found studies, approximately 30 molecules with in vitro and/or in vivo antitumor activity have been isolated (Figures 2 and 3 ).

Molecules or extracts that exhibited antitumor activity mainly act by inducing cell cycle arrest and/or apoptosis. 


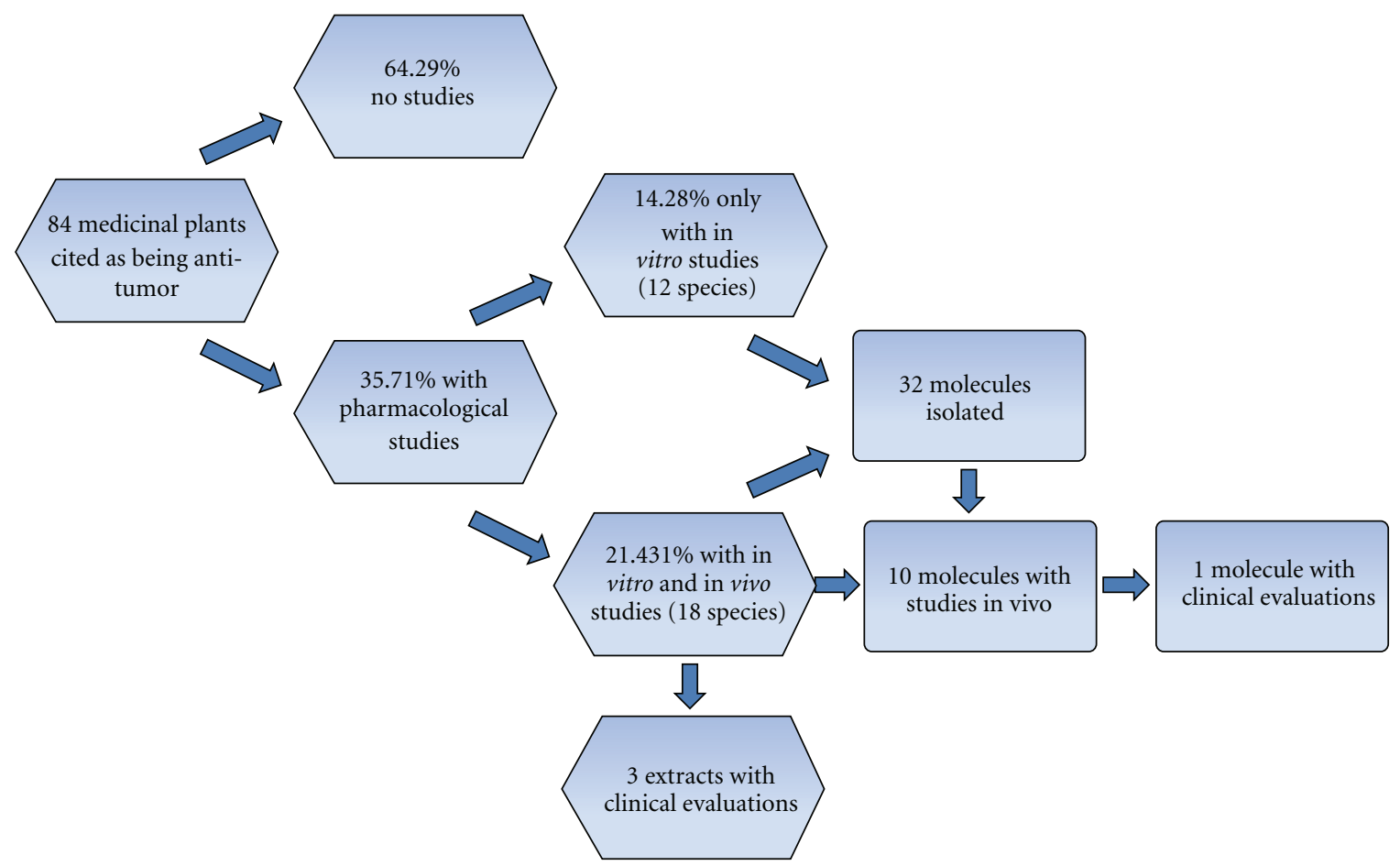

FIGURE 1: Level of pharmacological studies related to tumors of medicinal plants cited as being antitumor by traditional and nontraditional communities in Brazil.

Preclinical studies in cancer research have focused on the search for molecules that exhibit proapoptotic activity and promote cell cycle arrest. In our analysis, we found a great diversity of molecules of different chemical classes that exhibited anticancer activity, including alkaloids, peptides, glycoproteins, carotenoids, terpenes, carbohydrates, quinines, and phenolic compounds.

We summarize, in Table 1, the studies on the antitumor activity of each of the plant species we found in our search and the molecules that have been isolated from them.

\section{Discussion}

4.1. Survey of Ethnobotanical Studies. The highest numbers of studies citing antitumor plants were published between 2000 and 2008. This pattern is likely associated with the increase of publications relating to ethnobotanical studies conducted in Brazil during this time [106]. The low numbers of citations of plants identified as antitumor, with an overall average below 3 species per article, depicts in general, that local communities have a small repertoire of plants for the treatment of tumors when compared to more recurrent diseases and disorders, such as inflammation, flu, infections and parasites, which is focused on the most assiduous diseases. In a survey of the medicinal plants known and used by the people of the Caatinga biome, Albuquerque et al. [13] documented a total of 389 species, of which more than half were used to treat diseases of the digestive, respiratory, and genitourinary systems, while only 8 species $(2 \%)$ were used to treat tumors. However, it is difficult to diagnose cancer using traditional medicine because the signs and symptoms of different types of cancer are not specific and are confused with those of other diseases.

Most of the selected studies were conducted in urban and farming areas and areas with traditional healers, probably because: (a) these populations have a greater number of studies in Brazil (see [106]), (b) these populations have a greater knowledge of the plants used to treat tumors, and (c) these populations are more susceptible to the influences of other cultures and other external sources, such as the media (similar to what happened to the wide dissemination of Red Lapacho (Tabebuia impetiginosa, by magazine O'Cruzeiro published in 1967 reports of miraculous healing in cancer patients)) [107] and the public markets (defined as public spaces where many types of products are sold, including medicinal plants and their derivatives, and as a forum for the exchange of cultural information) [23]. The low similarity between the plant species from the populations located in the different ecosystems (14.29\%) suggests that the populations have a greater knowledge of medicinal plants from the local flora for the treatment of tumors.

4.2. Survey of Ethnobotanical Studies. Our survey of the 84 species of plants used in Brazil for the treatment of tumors likely represents only a fraction of the plants used for this purpose because studies published in local or regional journals may not be indexed in national and/or international databases. Additionally, not all communities in Brazil have been sufficiently studied.

The Euphorbiaceae, Fabaceae, Apocynaceae, and Asteraceae families, which had the largest number of species represented in this study, were also the most represented in 
<smiles>O=C(O)c1c(O)cccc1I</smiles>

Anacardic acid

$\mathrm{R}=8 \mathrm{Z}, 11 \mathrm{Z}, 14$, pentadecatrienyl $\mathrm{R}=8 \mathrm{Z}, 11 \mathrm{Z}$, pentadecadienyl

$\mathrm{R}=8 \mathrm{Z}$, pentadecenyl

$\mathrm{R}=$ pentadecyl<smiles>Cc1cc(C)c(O)c(O)c1</smiles>

Ascaridol<smiles>C=C1CC23CCC(C(C)(C)C(=O)O)C(C)(CC)C2CCC1C3</smiles>

Kaurenoic acid<smiles>COc1cc(OC)c2ccc(=O)oc2c1</smiles>

Benzyl isothiocyanate

\section{5,7-dimethoxycoumarin}

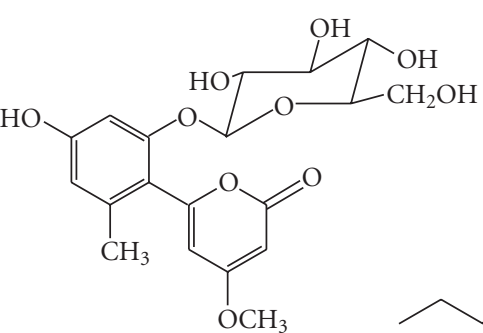

Aloenin<smiles>OCC1OC2OC1C(O)C(O)C2O</smiles>

Linamarin

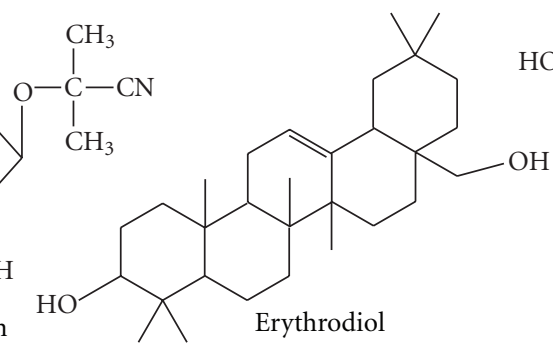

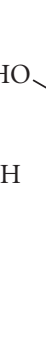

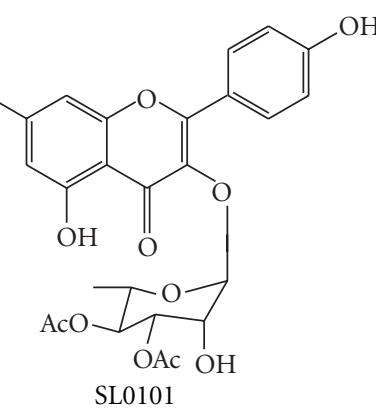<smiles>CCCCCCCCCCCCCCCCC(C)CCCCC(C)CCCC(C)CCCCCC</smiles>

Lycopene<smiles>[R]c1c(OC)cc2oc3c(c(=O)c2c1O)-c1cccc(O)c1OC3OC</smiles>

Boeravinones $\mathrm{H} \rightarrow \mathrm{R}=\mathrm{CH}_{3}$

Boeravinones $\mathrm{G} \rightarrow \mathrm{R}=\mathrm{H}$<smiles></smiles>

Sanguinarine<smiles>COCOCCO</smiles>

Chelerythrine<smiles>CCOC1(O)Cc2cc3c4cc2C(OCO4)C1c1ccc2c(c1C[NH+](C)C2)OCO3</smiles>

Chelidonine 


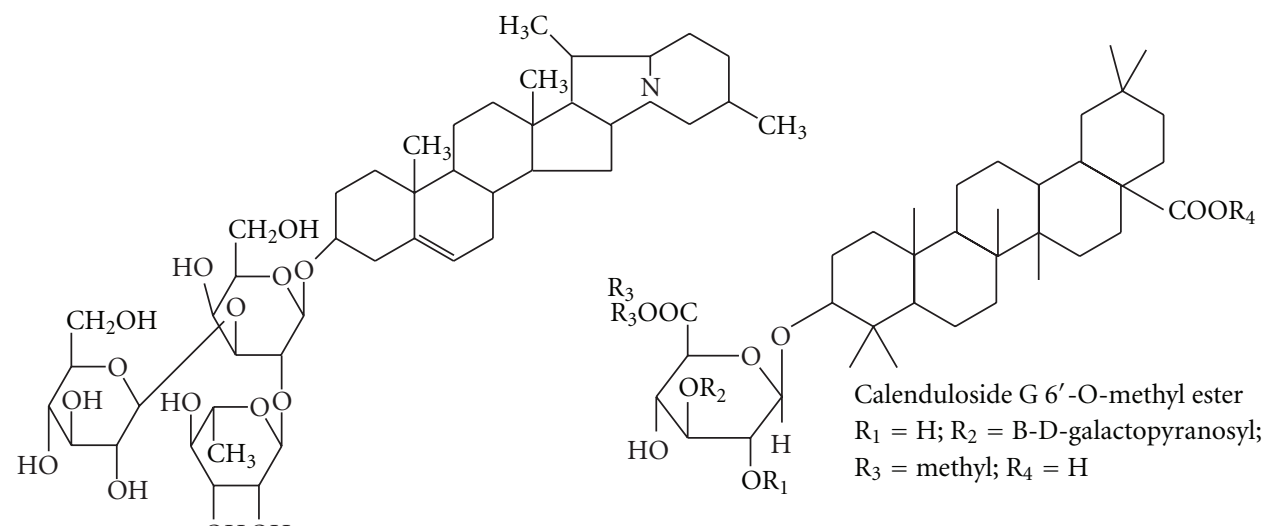

Calenduloside F 6' -O-n-butyl ester

$\mathrm{R}_{1}=\mathrm{H} ; \mathrm{R}_{2}=\mathrm{H} ; \mathrm{R}_{3}=\mathrm{n}$-butyl;

$\mathrm{R}_{4}=\mathrm{B}-\mathrm{D}$-glucopyranosyl

(b)

Figure 2: Molecules isolated from medicinal plants with antitumor activity in vitro.<smiles>COc1cc(C2Oc3cc(C4Oc5cc(O)cc(O)c5C(=O)C4O)ccc3OC2CO)ccc1O</smiles><smiles>CC1(C)CCC2=C(O1)c1ccccc1C(=O)C2=O</smiles>

B-lapachone<smiles>COc1cc(CNC(=O)CCCC/C=C/C(C)C)ccc1O</smiles><smiles>CC1=CC(=O)c2c(O)cccc2C1=O</smiles><smiles>CCC1CN2CCc3cc(OC)c(OC)cc3C2CC1CC1NCCc2cc(OC)c(OC)cc21</smiles>

Plumbagin

Emetine<smiles>O=C1c2cccc(O)c2C(=O)c2c(O)cc(CO)cc21</smiles>

Aloe emodin

FIGURE 3: Molecules isolated from medicinal plants with antitumor activity in vivo. 
an ethnopharmacological study aimed at selecting plants for use in experimental studies; one of the criteria for species selection was they present categories of use predefined, among those cited for the treatment of cancers, tumors, ulcers, sore mouth, and throat [4]. Four plant species should be highlighted for being highly cited in the studies and for their greater presence in the different ecosystems and regions of Brazil: A. vera, A. arborescens, E. tirucalli, and T. impetiginosa. These plants are widely publicized in Brazil by the virtual media as having anticancer properties. Furthermore, there are several products containing $A$. vera and T. impetiginosa that are explicitly marketed over the internet for the treatment of cancer; however, these claims lack scientific support.

This scenario, the low numbers of citations of plants identified as antitumor considering only one local community studied, has some implications if we want to use an ethnobotanical/ethnopharmacological approach for the search of new molecules with antineoplastic activity derived from the Brazilian flora. First, targeted ethnobotanical/ethnopharmacological studies in specific communities can easily result in no or few species being directly reported as antitumor. Should one want to perform a pharmacological study with less than 100 plants (triage) based on the popular knowledge of a single community, other selection criteria will be required besides a suggestion that a plant can be used to treat cancer. For the selection of species used in popular medicine, Santos and Elisabetsky [4] took into consideration not only the direct evidence that a plant was used for the treatment of cancer and tumors but also the signs and symptoms associated with certain cancers, which were related to the cell lines available for screening, and reports of the toxic effects common to chemotherapeutic agents (quantified by the order of importance). These selection criteria resulted in the identification of a greater number of candidate species for use in laboratory studies.

Second, a greater number of ethnobotanical/ethnopharmacological studies conducted and data collected on a regional scale will increase the possibilities of identifying new molecules with antitumor effects. For example, using lung and breast cancer cell lines, Lee and Houghton [108] evaluated the in vitro cytotoxic activity of seven plant species used in traditional Malaysian and Thai medicine to treat cancer. Eleven extracts from six plant species $(85.71 \%$ of the selected plants) exhibited antiproliferative activity against one of these cell lines, with $\mathrm{IC}_{50}$ values ranging from 2.7 to $35.8 \mu \mathrm{g} / \mathrm{mL}$. These extracts are of interest for future investigations.

4.3. Survey of Ethnobotanical Studies. The large number of plant species have not been analyzed for their antitumor potential $(64.29 \%, 54$ taxa) or have only been studied in vitro $(14.29 \%, 12$ taxa) indicates there is ample space in the field for future investigations of the anticancer activity of such plants in Brazil. In general, the plants that were used in various experimental studies showed significant results in the pharmacological models used, and these results corroborated their popular use. Many researchers selected plants used in alternative and complementary medicine to treat cancer, with the goal of evaluating the antitumoral activity. Satisfactory results has been found for both in vitro and in vivo $[109,110]$ activities, demonstrating that plant species used in popular medicine are a promising source for new molecules.

We propose the following suggestions for the plant species surveyed in this study: (1) for plants that have not been analyzed for their antitumor potential by any pharmacodynamic study, it is necessary to perform in vitro experiments with different solvents and using different cancer cell lines;,(2) for species from which active extracts have been isolated, including $H$. obovatus, $A$. hispidum, $P$. major, and $S$. occidentalis, it is necessary to identify the molecule(s) responsible for their biological activity, (3) for the species from which active extracts with known chemical structure(s) have been isolated and which have demonstrated significant activity in vitro, it is necessary to proceed with studies in vivo (e.g., V. odorata (cicloviolacina), C. officinalis (calenduloside), M. ilicifolia (pristimerina, 6-oxotingenol and erythrodiol), B. forficata (HY52), and C. langsdorffii (kaurenoic acid)), and (4) for the species that have met the previous requirements, it is necessary to make an extensive in vivo biological evaluation and subsequently proceed with clinical evaluations (e.g., S. marianum (silibinin), $T$. impetiginosa ( $\beta$-lapachone), P. scandens (plumbagin), and $C$. frutescens (capsaicin)). The species addressed here constitute interesting objects for future studies for the various professionals in the field of natural products.

\section{Acknowledgments}

The authors thank CNPq "Edital Universal" and CAPES for its financial support and grants to U. P. Albuquerque and J. G. Melo, respectively.

\section{References}

[1] BRASIL. Ministério da Saúde, Estimativa 2010: Incidência de Câncer no Brasil, Instituto Nacional do Câncer, Rio de Janeiro, Brazil, 2009.

[2] V. L. De Almeida, A. Leitão, L. C. B. Reina, C. A. Montanari, C. L. Donnici, and M. T. P. Lopes, "Cancer e agentes antineoplásicos específicos e ciclo-celular não específicos que interagem com o DNA: uma introdução," Quimica Nova, vol. 28, no. 1, pp. 118-129, 2005.

[3] S. Suresh, "Biomechanics and biophysics of cancer cells," Acta Materialia, vol. 55, no. 12, pp. 3989-4014, 2007.

[4] M. A. C. Santos and E. Elisabetsky, "Ethnopharmacology as a tool for the selection of medicinal plants for screening antitumour activity," Revista Brasileira de Plantas Medicinais, vol. 2, no. 1, pp. 7-17, 1999.

[5] R. B. De Oliveira and R. J. Alves, "Agentes antineoplásicos biorredutíveis: uma nova alternativa para o tratamento de tumores sólidos," Quimica Nova, vol. 25, no. 6 A, pp. 976984, 2002.

[6] B. R. Cassileth and G. Deng, "Complementary and alternative therapies for cancer," Oncologist, vol. 9, no. 1, pp. 80-89, 2004.

[7] G. M. Cragg, D. J. Newman, and K. M. Snader, "Natural products in drug discovery and development," Journal of Natural Products, vol. 60, no. 1, pp. 52-60, 1997. 
[8] H. J. Guchelaar, C. H. H. Ten Napel, E. G. E. De Vries, and N. H. Mulder, "Clinical, toxicological and pharmaceutical aspects of the antineoplastic drug taxol: a review," Clinical Oncology, vol. 6, no. 1, pp. 40-48, 1994.

[9] E. Elisabetsky and G. C. Souza, "Etnofarmacologia como ferramenta na busca de substâncias ativas," in Farmacognosia, C. M. O. Simões, E. P. Schenkel, G. Gosmann, J. C. P. Mello, L. A. Mentz, and P. R. Petrovick, Eds., pp. 107-122, Editora da UFRGS/ Editora da UFSC, 2004.

[10] I. K. Khafagi and A. Dewedar, "The efficiency of random versus ethno-directed research in the evaluation of Sinai medicinal plants for bioactive compounds," Journal of Ethnopharmacology, vol. 71, no. 3, pp. 365-376, 2000.

[11] D. F. Slish, H. Ueda, R. Arvigo, and M. J. Balick, "Ethnobotany in the search for vasoactive herbal medicines," Journal of Ethnopharmacology, vol. 66, no. 2, pp. 159-165, 1999.

[12] F. Engelke, "Fitoterápicos e legislação," Jornal Brasileiro de Fitomedicina, vol. 1, pp. 10-15, 2003.

[13] U. P. de Albuquerque, P. M. de Medeiros, A. L. S. de Almeida et al., "Medicinal plants of the caatinga (semi-arid) vegetation of NE Brazil: a quantitative approach," Journal of Ethnopharmacology, vol. 114, no. 3, pp. 325-354, 2007.

[14] J. G. De Melo, J. D. G. D. R. Martins, E. L. C. De Amorim, and U. P. De Albuquerque, "Qualidade de produtos a base de plantas medicinais comercializados no Brasil: castanhada-índia (Aesculus hippocastanum L.), capim-limão (Cymbopogon citratus (DC.) Stapf ) e centela (Centella asiatica (L.) Urban)," Acta Botanica Brasilica, vol. 21, no. 1, pp. 27-36, 2007.

[15] T. M. B. Garlet and B. E. Irgang, "Plantas medicinais utilizadas na medicina popular por mulheres trabalhadoras rurais de Cruz Alta, Rio Grande do Sul, Brasil," Revista Brasileira de Plantas Medicinais, vol. 4, no. 1, pp. 9-18, 2001.

[16] E. L. C. Soares, G. S. Vendruscolo, S. M. Eisinger, and R. A. Záchia, "Estudo etnobotânico do uso dos recursos vegetais em São João do Polêsine, RS, Brasil, no período de outubro de 1999 a junho de 2001-I-Origem e fluxo do conhecimento," Revista Brasileira de Plantas Medicinais, vol. 6, no. 3, pp. 69-95, 2004.

[17] Y. Sun, X. Jiang, S. Chen, and B. D. Price, "Inhibition of histone acetyltransferase activity by anacardic acid sensitizes tumor cells to ionizing radiation," FEBS Letters, vol. 580, no. 18, pp. 4353-4356, 2006.

[18] C. G. Mothé, I. A. De Souza, and G. M. T. Calazans, "Antitumor activity of cashew gum from Anacardium occidentale L," Agro Food Industry Hi-Tech, vol. 19, no. 6, pp. 50-52, 2008.

[19] G. Vicente, "Nonsurgical treatment of basal cellcarcinoma using cashew extract," Otolaryngology, vol. 141, p. 44, 2009.

[20] A. I. Rea, J. M. Schmidt, W. N. Setzer, S. Sibanda, C. Taylor, and E. T. Gwebu, "Cytotoxic activity of Ozoroa insignis from Zimbabwe,” Fitoterapia, vol. 74, pp. 732-735, 2003.

[21] M. F. Agra, E. Locatelli, E. A. Rocha, G. S. Baracho, and S. C. Formiga, "Plantas medicinais nos cariris velhos, paraibaparte II: subclasses magnoliidae, caryophyllidae, dilleniidae e rosidae," Revista Brasileira de Farmacia, vol. 77, no. 3, pp. 97$102,1996$.

[22] M. F. Agra, K. N. Silva, I. J. L. D. Basílio, P. F. Freitas, and J. Barbosa-Filho, "Survey of medicinal plants used in the region Northeast of Brazil," Brazilian Journal of Pharmacognosy, vol. 18 , pp. 472-508, 2008.

[23] U. P. de Albuquerque, J. M. Monteiro, M. A. Ramos, and E. L. C. de Amorim, "Medicinal and magic plants from a public market in northeastern Brazil," Journal of Ethnopharmacology, vol. 110, no. 1, pp. 76-91, 2007.
[24] J. M. Monteiro, U. P. D. Albuquerque, E. M. D. F. LinsNeto, E. L. D. Araújo, and E. L. C. D. Amorim, "Use patterns and knowledge of medicinal species among two rural communities in Brazil's semi-arid northeastern region," Journal of Ethnopharmacology, vol. 105, no. 1-2, pp. 173-186, 2006.

[25] M. F. Agra, G. S. Baracho, K. Nurit, I. J. L. D. Basílio, and V. P. M. Coelho, "Medicinal and poisonous diversity of the flora of "Cariri Paraibano", Brazil," Journal of Ethnopharmacology, vol. 111, no. 2, pp. 383-395, 2007.

[26] J. A. Smith, C. E. Poteet-Smith, Y. Xu, T. M. Errington, S. M. Hecht, and D. A. Lannigan, "Identification of the first specific inhibitor of p90 ribosomal S6 kinase (RSK) reveals an unexpected role for RSK in cancer cell proliferation," Cancer Research, vol. 65, no. 3, pp. 1027-1034, 2005.

[27] C. S. P. Da Silva and C. E. B. Proença, "Use and availability of medicinal resources in Ouro Verde de Goiás, Goiás State, Brazil," Acta Botanica Brasilica, vol. 22, no. 2, pp. 481-492, 2008.

[28] D. C. Endringer, J. M. Pezzuto, and F. C. Braga, "NF$\kappa \mathrm{B}$ inhibitory activity of cyclitols isolated from Hancornia speciosa," Phytomedicine, vol. 16, no. 11, pp. 1064-1069, 2009.

[29] R. A. Voeks and A. Leony, "Forgetting the forest: assessing medicinal plant erosion in eastern Brazil," Economic Botany, vol. 58, supplement, pp. S294-S306, 2004.

[30] M. L. de Mesquita, J. E. de Paula, C. Pessoa et al., "Cytotoxic activity of Brazilian Cerrado plants used in traditional medicine against cancer cell lines," Journal of Ethnopharmacology, vol. 123, no. 3, pp. 439-445, 2009.

[31] L. Calábria, G. T. Cuba, S. M. Hwang et al., "Ethnobotanical and ethnopharmacological survey of medicinal plants in Indianopolis, Minas Gerais, Brazil," Revista Brasileira de Plantas Medicinais, vol. 10, no. 1, pp. 49-63, 2008.

[32] M. N. Rennó, G. M. Barbosa, P. Zancan et al., "Crude ethanol extract from babassu (Orbignya speciosa): cytotoxicity on tumoral and non-tumoral cell lines," Anais da Academia Brasileira de Ciencias, vol. 80, no. 3, pp. 467-476, 2008.

[33] R. A. Mothana, U. Lindequist, R. Gruenert, and P. J. Bednarski, "Studies of the in vitro anticancer, antimicrobial and antioxidant potentials of selected Yemeni medicinal plants from the island Soqotra," BMC Complementary and Alternative Medicine, vol. 9, article 7, 2009.

[34] N. Deepa and N. N. Rajendran, "Anti-tumor activity of Acanthospermum hispidum DC on dalton ascites lymphoma in mice," Natural Product Sciences, vol. 13, no. 3, pp. 234-240, 2007.

[35] C. F. C. B. R. De Almeida, T. C. De Lima E Silva, E. L. C. De Amorim, M. B. D. S. Maia, and U. P. De Albuquerque, "Life strategy and chemical composition as predictors of the selection of medicinal plants from the caatinga (Northeast Brazil)," Journal of Arid Environments, vol. 62, no. 1, pp. 127142, 2005.

[36] C. F. C. B. R. Almeida, E. L. C. Amorim, U. P. Albuquerque, and M. B. S. Maia, "Medicinal plants popularly used in the Xingó region-a semi-arid location in Northeastern Brazil," Journal of Ethnobiology and Ethnomedicine, vol. 2, article 15, 2006.

[37] G. S. Vendruscolo, C. M. O. Simões, and L. A. Mentz, "Etnobotânica no Rio Grande do Sul: análise comparativa entre o conhecimento original e atual sobre as plantas medicinais nativas," Pesquisa Botânica, vol. 56, pp. 285-320, 2005. 
[38] M. Ukiya, T. Akihisa, K. Yasukawa, H. Tokuda, T. Suzuki, and Y. Kimura, "Anti-inflammatory, anti-tumor-promoting, and cytotoxic activities of constituents of marigold (Calendula officinalis) flowers," Journal of Natural Products, vol. 69, no. 12, pp. 1692-1696, 2006.

[39] G. Deep and R. Agarwal, "Chemopreventive efficacy of silymarin in skin and prostate cancer," Integrative Cancer Therapies, vol. 6, no. 2, pp. 130-145, 2007.

[40] N. Bhatia, J. Zhao, D. M. Wolf, and R. Agarwal, "Inhibition of human carcinoma cell growth and DNA synthesis by silibinin, an active constituent of milk thistle: comparison with silymarin," Cancer Letters, vol. 147, no. 1-2, pp. 77-84, 1999.

[41] D. Gupta, K. Podar, Y. T. Tai et al., “ $\beta$-lapachone, a novel plant product, overcomes drug resistance in human multiple myeloma cells," Experimental Hematology, vol. 30, no. 7, pp. 711-720, 2002.

[42] H. J. Park, K. J. Ahn, S. D. Ahn et al., "Susceptibility of cancer cells to $\beta$-lapachone is enhanced by ionizing radiation," International Journal of Radiation Oncology Biology Physics, vol. 61, no. 1, pp. 212-219, 2005.

[43] L. R. S. Gazzaneo, R. F. Paiva de Lucena, and U. P. de Albuquerque, "Knowledge and use of medicinal plants by local specialists in an region of Atlantic Forest in the state of Pernambuco (Northeastern Brazil)," Journal of Ethnobiology and Ethnomedicine, vol. 1, article 9, 2005.

[44] A. S. Botsaris, "Plants used traditionally to treat malaria in Brazil: the archives of Flora Medicinal," Journal of Ethnobiology and Ethnomedicine, vol. 3, article 18, 2007.

[45] R. R. B. Negrelle and K. R. C. Fornazzari, "Estudo etnobotânico em duas comunidades rurais (Limeira e Ribeirão Grande) de Guaratuba (Paraná, Brasil)," Revista Brasileira de Plantas Medicinais, vol. 9, no. 2, pp. 36-54, 2007.

[46] S. Castellucci, M. I. S. Lima, N. Nivaldo, and J. G. W. Marques, "Plantas medicinais relatadas pela comunidade residente na estação ecológica de Jataí, Município de Luís Antônio/SP: uma abordagem etnobotânica," Revista Brasileira de Plantas Medicinais, vol. 3, no. 1, pp. 51-60, 2000.

[47] E. M. Costa-Neto and M. V. M. Oliveira, "The use of medicinal plants in the county of Tanquinho, State of Bahia, Northeastern Brazil," Revista Brasileira de Plantas Medicinais, vol. 2, no. 2, pp. 1-8, 2000.

[48] G. P. Roman, E. Neagu, V. Moroeanu, and G. L. Radu, "Concentration of Symphytum officinale extracts with cytostatic activity by tangential flow ultrafiltration," Roumanian Biotechnological Letters, vol. 13, pp. 4008-4013, 2008.

[49] A. M. Borba and M. Macedo, "Plantas medicinais usadas para a saúde bucal pela comunidade do bairro Santa Cruz, Chapada dos Guimarães, MT, Brasil," Acta Botanica Brasilica, vol. 20, no. 4, pp. 771-782, 2006.

[50] G. C. Souza, A. P. S. Haas, G. L. Von Poser, and E. Elisabetsky, "Community home pharmacies in Maquiné (RS) an ethnopharmacologial evaluation," Revista Brasileira de Plantas Medicinais, vol. 6, no. 2, pp. 83-91, 2004.

[51] D. Alesiani, R. Cicconi, M. Mattei, C. Montesano, R. Bei, and A. Canini, "Cell cycle arrest and differentiation induction by 5,7-dimethoxycoumarin in melanoma cell lines," International Journal of Oncology, vol. 32, no. 2, pp. 425-434, 2008.

[52] R. B. van Breemen and N. Pajkovic, "Multitargeted therapy of cancer by lycopene," Cancer Letters, vol. 269, no. 2, pp. 339351, 2008.

[53] N. Miyoshi, K. Uchida, T. Osawa, and Y. Nakamura, "Selective cytotoxicity of benzyl isothiocyanate in the proliferating fibroblastoid cells," International Journal of Cancer, vol. 120, no. 3, pp. 484-492, 2007.

[54] M. F. T. Medeiros, V. S. Fonseca, and R. H. P. Andreata, "Plantas medicinais e seus usos pelos sitiantes da Reserva Rio das Pedras, Mangaratiba, RJ, Brasil," Acta Botanica Brasilica, vol. 18, pp. 391-399, 2004.

[55] C. D. De Souza and J. M. Felfili, "Uso de plantas medicinais na região de alto paraíso de goiás, GO, Brasil," Acta Botanica Brasilica, vol. 20, no. 1, pp. 135-142, 2006.

[56] M. G. L. Brandão, N. N. S. Zanetti, P. Oliveira, C. F. F. Grael, A. C. P. Santos, and R. L. M. Monte-Mór, "Brazilian medicinal plants described by 19th century European naturalists and in the Official Pharmacopoeia," Journal of Ethnopharmacology, vol. 120, no. 2, pp. 141-148, 2008.

[57] O. Shirota, H. Morita, K. Takeya, H. Itokawa, and Y. Iitaka, "Cytotoxic aromatic triterpenes from Maytenus ilicifolia and Maytenus chuchuhuasca," Journal of Natural Products, vol. 57, no. 12, pp. 1675-1681, 1994.

[58] P. M. D. Costa, P. M. P. Ferreira, V. D. S. Bolzani et al., "Antiproliferative activity of pristimerin isolated from Maytenus ilicifolia (Celastraceae) in human HL-60 cells," Toxicology in Vitro, vol. 22, no. 4, pp. 854-863, 2008.

[59] A. Ohsaki, Y. Imai, M. Naruse, S. I. Ayabe, K. Komiyama, and J. Takashima, "Four new triterpenoids from Maytenus ilicifolia," Journal of Natural Products, vol. 67, no. 3, pp. 469471, 2004.

[60] M. R. A. Dos Santos, M. R. De Lima, and M. D. G. R. Ferreira, "Uso de plantas medicinais pela população de Ariquemes, em Rondônia," Horticultura Brasileira, vol. 26, no. 2, pp. 244250, 2008.

[61] M. I. A. Goncalves and D. T. O. Martins, "Plantas medicinais usadas pela populacao do municipio de Santo Antonio de Leverger, Mato Grosso, Brasil," Revista Brasileira de Farmacia, vol. 79, no. 3-4, pp. 56-61, 1998.

[62] F. R. F. Nascimento, G. V. B. Cruz, P. V. S. Pereira et al., "Ascitic and solid Ehrlich tumor inhibition by Chenopodium ambrosioides L. treatment," Life Sciences, vol. 78, no. 22, pp. 2650-2653, 2006.

[63] T. Efferth, A. Olbrich, A. Sauerbrey, D. D. Ross, E. Gebhart, and M. Neugebauer, "Activity of ascaridol from the anthelmintic herb Chenopodium anthelminticum L. against sensitive and multidrug-resistant tumor cells," Anticancer Research, vol. 22, no. 6 C, pp. 4221-4224, 2002.

[64] G. S. Vendruscolo and L. A. Mentz, "Estudo da concordância das citações de uso e importância das espécies e famílias utilizadas como medicinais pela comunidade do bairro Ponta Grossa, Porto Alegre, RS, Brasil," Acta Botanica Brasilica, vol. 20, no. 2, pp. 367-382, 2006.

[65] G. S. Hirschmann and A. R. De Arias, "A survey of medicinal plants of Minas Gerais, Brazil," Journal of Ethnopharmacology, vol. 29, no. 2, pp. 159-172, 1990.

[66] F. M. C. De Barros, K. N. Pereira, G. D. Zanetti, and B. M. Heinzmann, "Plantas de uso medicinal no Município de São Luiz Gonzaga, RS, Brasil," Latin American Journal of Pharmacy, vol. 26, no. 5, pp. 652-662, 2007.

[67] B. G. Brasileiro, V. R. Pizziolo, D. Soares Raslan, C. Mashrouah Jamal, and D. Silveira, "Antimicrobial and cytotoxic activities screening of some Brazilian medicinal plants used in Governador Valadares district," Revista Brasileira de Ciencias Farmaceuticas/Brazilian Journal of Pharmaceutical Sciences, vol. 42, no. 2, pp. 195-202, 2006.

[68] C. A. Idibie, H. Davids, and S. E. Iyuke, "Cytotoxicity of purified cassava linamarin to a selected cancer cell lines," 
Bioprocess and Biosystems Engineering, vol. 30, no. 4, pp. 261269, 2007.

[69] V. S. P. Chaturvedula, J. K. Schilling, S. Malone, J. H. Wisse, M. C. M. Werkhoven, and D. G. I. Kingston, "New cytotoxic triterpene acids from aboveground parts of Manihot esculenta from the Suriname rainforest," Planta Medica, vol. 69, no. 3, pp. 271-274, 2003.

[70] M. P. Moretão, A. R. Zampronio, P. A. J. Gorin, M. Iacomini, and M. B. M. Oliveira, "Induction of secretory and tumoricidal activities in peritoneal macrophages activated by an acidic heteropolysaccharide (ARAGAL) from the gum of Anadenanthera colubrina (Angico branco)," Immunology Letters, vol. 93, no. 2-3, pp. 189-197, 2004.

[71] H. Lim, M. K. Kim, Y. Lim, Y. H. Cho, and C. H. Lee, "Inhibition of cell-cycle progression in HeLa cells by HY52, a novel cyclin-dependent kinase inhibitor isolated from Bauhinia forficata," Cancer Letters, vol. 233, no. 1, pp. 89-97, 2006.

[72] L. V. Costa-Lotufo, G. M. A. Cunha, P. A. M. Farias et al., "The cytotoxic and embryotoxic effects of kaurenoic acid, a diterpene isolated from Copaifera langsdorffii oleo-resin," Toxicon, vol. 40, no. 8, pp. 1231-1234, 2002.

[73] S. R. M. Lima, V. F. Veiga, H. B. Christo, A. C. Pinto, and P. D. Fernandes, "In vivo and in vitro studies on the anticancer activity of Copaifera multijuga Hayne and its fractions," Phytotherapy Research, vol. 17, no. 9, pp. 1048-1053, 2003.

[74] A. I. Calderón, Y. Vázquez, P. N. Solís et al., "Screening of Latin American plants for cytotoxic activity," Pharmaceutical Biology, vol. 44, no. 2, pp. 130-140, 2006.

[75] L. C. Di Stasi, C. A. Hiruma, E. M. Guimaraes, and C. M. Santos, "Medicinal plants popularly used in Brazilian Amazon," Fitoterapia, vol. 65, no. 6, pp. 529-540, 1994.

[76] P. Lissoni, F. Rovelli, F. Brivio et al., "A randomized study of chemotherapy versus biochemistry with chemotherapy plus aloe arborescens in patients with metastatic cancer," In Vivo, vol. 23, no. 1, pp. 171-176, 2009.

[77] F. Furukawa, A. Nishikawa, T. Chihara et al., "Chemopreventive effects of Aloe arborescens on N-nitrosobis(2oxopropyl)amine-induced pancreatic carcinogenesis in hamsters," Cancer Letters, vol. 178, no. 2, pp. 117-122, 2002.

[78] G. Z. Jin, H. J. Quan, J. Koyanagi et al., “4'-O-Alkyaloenin derivatives and their sulfates directed toward overcoming multidrug resistance in tumor cells," Cancer Letters, vol. 218, no. 1, pp. 15-20, 2005.

[79] P. A. Dorigoni, P. C. Ghedini, L. F. Fróes, K. C. Baptista, A. B. M. Ethur, and B. Baldisserotto, "Levantamento de dados sobre plantas medicinais de uso popular no município de São João do Polêsine, RS, Brasil—I—relação entre enfermidades e espécies utilizadas," Revista Brasileira de Plantas Medicinais, vol. 4, pp. 69-79, 2001.

[80] G. S. Vendruscolo, S. M. K. Rates, and L. A. Mentz, "Dados químicos e farmacológicos sobre as plantas utilizadas como medicinais pela comunidade do bairro Ponta Grossa, Porto Alegre, Rio Grande do Sul," Revista Brasileira de Farmacognosia, vol. 15, pp. 361-372, 2005.

[81] R. C. T. Moreira, L. C. D. B. Costa, R. C. S. Costa, and E. A. Rocha, "Abordagem etnobotânica acerca do uso de plantas medicinais na Vila Cachoeira, Ilhéus, Bahia, Brasil," Acta Farmaceutica Bonaerense, vol. 21, no. 3, pp. 205-211, 2002.

[82] T. Pecere, M. V. Gazzola, C. Mucignat et al., "Aloe-emodin is a new type of anticancer agent with selective activity against neuroectodermal tumors," Cancer Research, vol. 60, no. 11, pp. 2800-2804, 2000.
[83] N. Akev, G. Turkay, A. Can et al., "Tumour preventive effect of Aloe vera leaf pulp lectin (Aloctin I) on Ehrlich ascites tumours in mice," Phytotherapy Research, vol. 21, no. 11, pp. 1070-1075, 2007.

[84] M. A. C. Pilla, M. C. D. M. Amorozo, and A. Furlan, "Obtenção e uso das plantas medicinais no distrito de Martim Francisco, Município de Mogi-Mirim, SP, Brasil,” Acta Botanica Brasilica, vol. 20, no. 4, pp. 789-802, 2006.

[85] R. R. B. Negrelle, M. I. Tomazzoni, M. F. Ceccon, and T. P. Valente, "Estudo etnobotânico junto à Unidade Saúde da Família Nossa Senhora dos Navegantes: subsídios para o estabelecimento de programa de fitoterápicos na Rede Básica de Saúde do Município de Cascavel (Paraná)," Revista Brasileira de Plantas Medicinais, vol. 9, no. 3, pp. 6-22, 2007.

[86] C. P. Cordero, S. Gómez-González, C. J. León-Acosta, S. J. Morantes-Medina, and F. A. Aristizabal, "Cytotoxic activity of five compounds isolated from Colombian plants," Fitoterapia, vol. 75, no. 2, pp. 225-227, 2004.

[87] V. E. G. Rodrigues and D. A. Carvalho, "Levantamento etnobotânico de plantas medicinais no domínio dos cerrados na região do Alto Rio Grande-Minas Gerais," Revista Brasileira de Plantas Medicinais, vol. 9, pp. 17-35, 2002.

[88] K. A. Manu and G. Kuttan, "Anti-metastatic potential of Punarnavine, an alkaloid from Boerhaavia diffusa Linn," Immunobiology, vol. 214, no. 4, pp. 245-255, 2009.

[89] A. Ahmed-Belkacem, S. Macalou, F. Borrelli et al., "Nonprenylated rotenoids, a new class of potent breast cancer resistance protein inhibitors," Journal of Medicinal Chemistry, vol. 50, no. 8, pp. 1933-1938, 2007.

[90] S. J. Biswas, N. Bhattacharjee, and A. R. Khuda-Bukhsh, "Efficacy of a plant extract (Chelidonium majus L.) in combating induced hepatocarcinogenesis in mice," Food and Chemical Toxicology, vol. 46, no. 5, pp. 1474-1487, 2008.

[91] R. Nawrot, M. Wolun-Cholewa, and A. Gozdzicka-Józefiak, "Nucleases isolated from Chelidonium majus L. milky sap can induce apoptosis in human cervical carcinoma HeLa cells but not in Chinese Hamster Ovary CHO cells," Folia Histochemica et Cytobiologica, vol. 46, no. 1, pp. 79-83, 2008.

[92] Á. Kemény-Beke, J. Aradi, J. Damjanovich et al., "Apoptotic response of uveal melanoma cells upon treatment with chelidonine, sanguinarine and chelerythrine," Cancer Letters, vol. 237, no. 1, pp. 67-75, 2006.

[93] R. Velasco-Lezama, R. Tapia-Aguilar, R. Román-Ramos, E. Vega-Avila, and MA. S. Pérez-Gutiérrez, "Effect of Plantago major on cell proliferation in vitro," Journal of Ethnopharmacology, vol. 103, no. 1, pp. 36-42, 2006.

[94] M. Ozaslan, I. D. Karagöz, M. E. Kalender, I. H. Kilic, I. Sari, and A. Karagöz, "In vivo antitumoral effect of Plantago major L. extract on Balb/C mouse with Ehrlich ascites tumor," American Journal of Chinese Medicine, vol. 35, no. 5, pp. 841851, 2007.

[95] Y. L. Hsu, C. Y. Cho, P. L. Kuo, Y. T. Huang, and C. C. Lin, "Plumbagin (5-hydroxy-2-methyl-1,4-naphthoquinone) induces apoptosis and cell cycle arrest in A549 cells through p53 accumulation via c-Jun NH -terminal kinase-mediated phosphorylation at serine 15 in vitro and in vivo," Journal of Pharmacology and Experimental Therapeutics, vol. 318, no. 2, pp. 484-494, 2006.

[96] K.-H. Xu and D.-P. Lu, "Plumbagin induces ROS-mediated apoptosis in human promyelocytic leukemia cells in vivo," Leukemia Research, vol. 34, no. 5, pp. 658-665, 2010.

[97] M. Möller and M. Wink, "Characteristics of apoptosis induction by the alkaloid emetine in human tumour cell lines," Planta Medica, vol. 73, no. 13, pp. 1389-1396, 2007. 
[98] S. Siddiqui, D. Firat, and S. Olshin, "Phase II study of emetine (NSC 33669) in the treatment of solid tumors," Cancer Chemotherapy Reports, vol. 57, no. 4, pp. 423-428, 1973.

[99] T. Maoka, K. Mochida, M. Kozuka et al., "Cancer chemopreventive activity of carotenoids in the fruits of red paprika Capsicum annuum L," Cancer Letters, vol. 172, no. 2, pp. 103-109, 2001.

[100] R. Zhang, I. Humphreys, R. P. Sahu, Y. Shi, and S. K. Srivastava, "In vitro and in vivo induction of apoptosis by capsaicin in pancreatic cancer cells is mediated through ROS generation and mitochondrial death pathway," Apoptosis, vol. 13, no. 12, pp. 1465-1478, 2008.

[101] J. Li, Q. Li, T. Feng et al., "Antitumor activity of crude polysaccharides isolated from Solanum nigrum Linne on U14 cervical carcinoma bearing mice," Phytotherapy Research, vol. 21, no. 9, pp. 832-840, 2007.

[102] Y. B. Ji, S. Y. Gao, C. F. Ji, and X. Zou, "Induction of apoptosis in HepG cells by solanine and Bcl-2 protein," Journal of Ethnopharmacology, vol. 115, no. 2, pp. 194-202, 2008.

[103] R. F. Vieira and M. V. M. Martins, "Genetic resources on Brazilian Cerrado medicinal plantsRecursos genéticos de plantas medicinals do cerrado: uma compilação de dados," Revista Brasileira de Plantas Medicinais, vol. 3, no. 1, pp. 1336, 2000 .

[104] E. A. P. Franco and R. F. M. Barros, "Uso e diversidade de plantas medicinais no Quilombo Olho D'água dos Pires, Esperantina, Piauí," Revista Brasileira de Plantas Medicinais, vol. 8, no. 3, pp. 78-88, 2006.

[105] S. Perwaiz and S. Sultana, "Antitumorigenic effect of crude extract of Viola odorata on DMBA- induced two stage skin carcinogenesis in the Swiss albino mice," Asia Pacific Journal of Pharmacology, vol. 13, no. 1, pp. 43-50, 1998.

[106] F. C. Oliveira, U. P. Albuquerque, V. S. Fonseca-Kruel, and N. Hanazaki, "Advances in ethnobotany research in Brazil," in Recife: Sociedade Brasileira de Etnobiologia, U. P. Albuquerque and N. Hanazaki, Eds., pp. 153-188, Núcleo de Publicações em Ecologia e Etnobotânica Aplicada, 2010.

[107] J. R. Castellanos, J. M. Prieto, and M. Heinrich, "Red Lapacho (Tabebuia impetiginosa) —a global ethnopharmacological commodity?" Journal of Ethnopharmacology, vol. 121, no. 1, pp. 1-13, 2009.

[108] C. C. Lee and P. Houghton, "Cytotoxicity of plants from Malaysia and Thailand used traditionally to treat cancer," Journal of Ethnopharmacology, vol. 100, no. 3, pp. 237-243, 2005.

[109] Z. Tayarani-Najaran, S. A. Emami, J. Asili, A. Mirzaei, and S. H. Mousavi, "Analyzing cytotoxic and apoptogenic properties of Scutellaria litwinowii root extract on cancer cell lines," Evidence-Based Complementary and Alternative Medicine. In press.

[110] T. Matsuda, K. Maekawa, K. Asano, and T. Hisamitsu, "Suppressive effect of Juzen-Taiho-To on lung metastasis of B16 melanoma cells in vivo," Evidence-Based Complementary and Alternative Medicine. In press. 


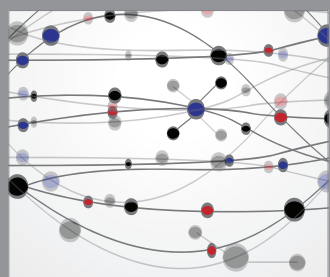

The Scientific World Journal
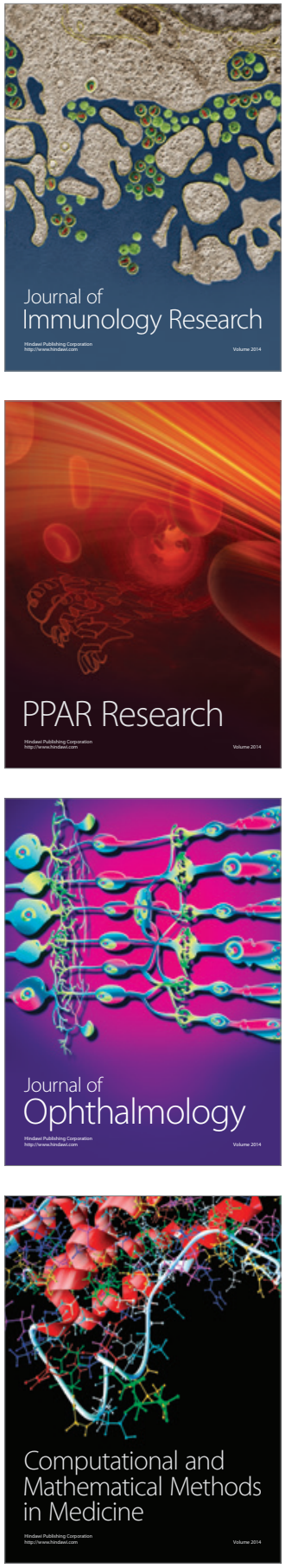

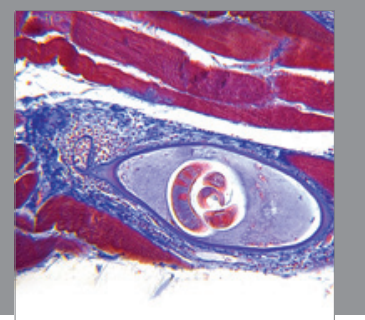

Gastroenterology

Research and Practice
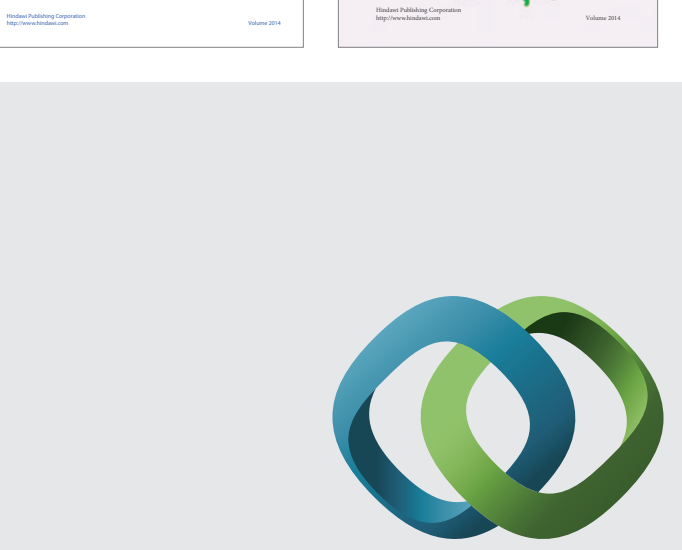

\section{Hindawi}

Submit your manuscripts at

http://www.hindawi.com
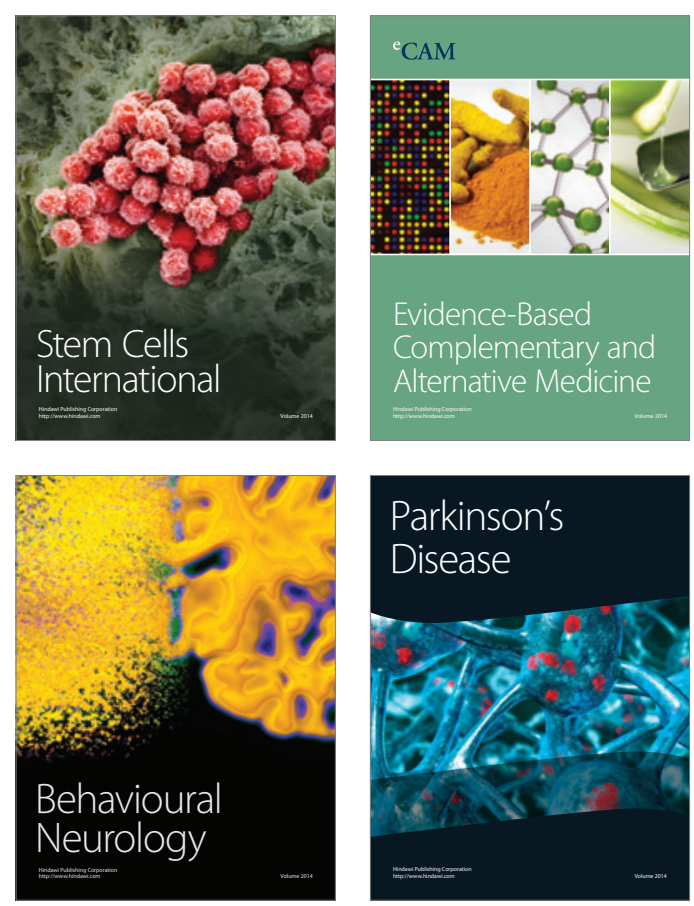

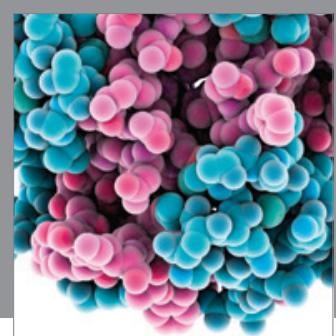

Journal of
Diabetes Research

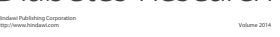

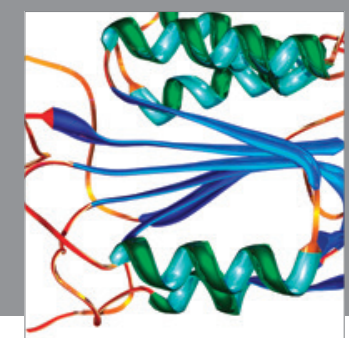

Disease Markers
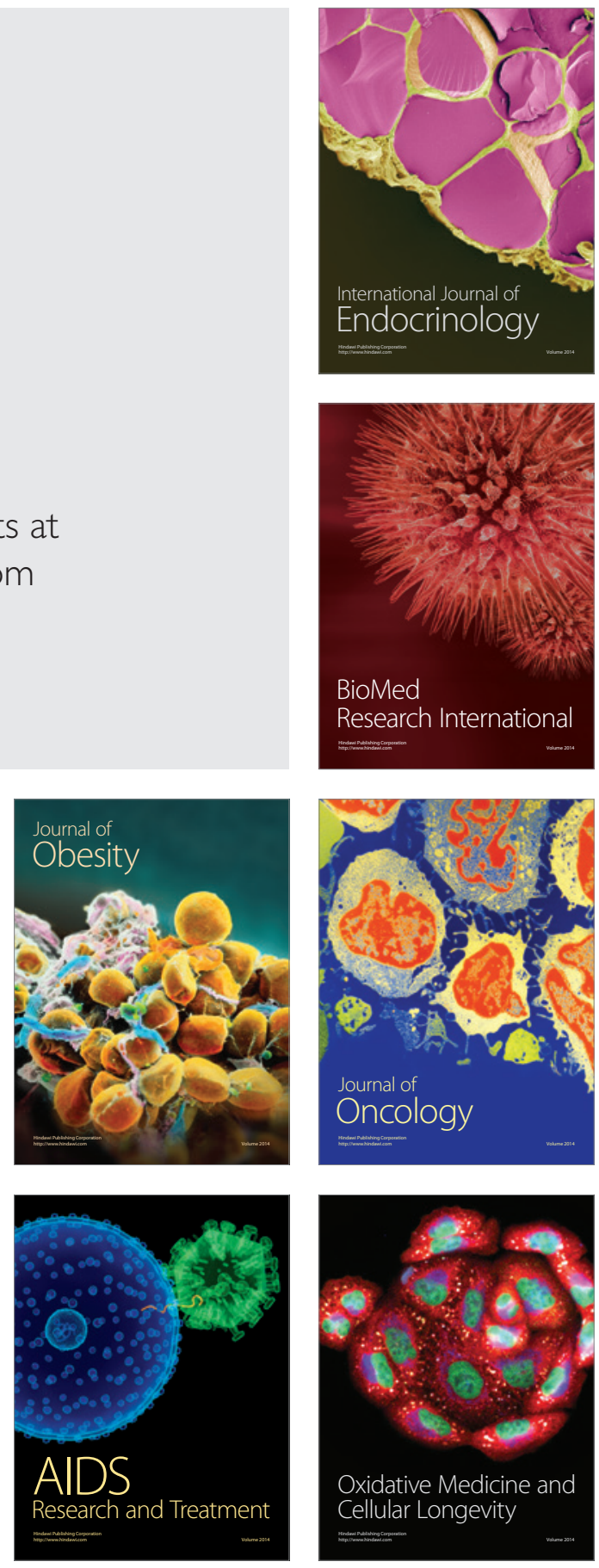